\title{
Pulsing on the postharvest physiology of two cultivars of Polianthes tuberosa $\mathrm{L}$.
}

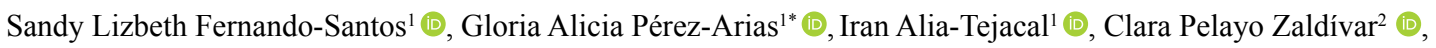 \\ Víctor López-Martínez ${ }^{1}$ (1), Porfirio Juárez-López ${ }^{1}$ (1), Dagoberto Sánchez-Guillén ${ }^{1}$ (1) \\ ${ }^{1}$ Universidad Autónoma del Estado de Morelos, Facultad de Ciencias Agropecuarias, Cuernavaca, Morelos, México. \\ ${ }^{2}$ Universidad Autónoma Metropolitana, Departamento de Biotecnología, Ciudad de México, Mexico.
}

\begin{abstract}
The effect of pulsing on the postharvest behavior of cut tuberose was evaluated in the cultivars 'Mexican Single' and 'The Pearl'. Spikes of both were harvested with 1 or 2 of their basal buds open and treated with $20 \%$ sucrose and $200 \mathrm{mg}$ of hydroxyquinoline citrate (sucrose + HQC). Pulsing increased the relative fresh weight of spikes, although water uptake in 'The Pearl' was greater regardless. After 5 days, visual quality was scored as 'excellent' and 'good' in 'Mexican Single' and 'The Pearl', respectively, and the greatest number of open and of senescent flowers occurred in the latter independent of pulsing. $\mathrm{CIE} L * \mathrm{C}^{*} \mathrm{~h}$ values and total sugars increased more noticeably among pulsed florets in 'The Pearl', whereas higher rates of respiration occurred in the unpulsed spikes of 'Mexican Single'. Catalase activity was constant in 'The Pearl', although superoxide dismutase and peroxidase activities were higher and similar to, respectively, those of 'Mexican Single'. These differences in physical, physiological and enzymatic behavior are important to consider when developing postharvest conservation and management strategies that are specific for each variety.
\end{abstract} Keywords: catalase, peroxidase, soluble sugars, superoxide dismutase, tuberose.

\section{Resumo}

Pulsing na fisiologia pós-colheita de duas cultivares de Polianthes tuberosa $\mathbf{L}$.

O efeito do pulsing no comportamento pós-colheita de angélica foi avaliado para as cultivares 'Mexican Single' e 'The Pearl'. As inflorescências de ambas foram colhidas com 1 ou 2 de seus botões basais abertos e tratadas com $20 \%$ de sacarose e $200 \mathrm{mg}$ de citrato de hidroxiquinolina (sacarose $+\mathrm{HQC}$ ). O pulsing aumentou o peso relativo fresco das inflorescências, embora a captação de água na 'The Pearl' tenha sido maior. Após 5 dias, a qualidade visual foi classificada como 'excelente' e 'boa' em 'Mexican Single' e 'The Pearl', respectivamente, e o maior número de flores abertas e senescentes ocorreu no último pulsing. Os valores de CIE L* $\mathrm{C}^{*} \mathrm{~h}$ e açúcares totais aumentaram entre as flores tratadas de 〈The Pearl», enquanto taxas mais altas de respiração ocorreram na testemunha de «Mexican Single〉. A atividade da catalase foi constante em «The Pearl〉, embora as atividades de superóxido dismutase e peroxidase tenham sido mais altas e semelhantes, respectivamente, às da «Mexican Single». Essas diferenças no comportamento físico, fisiológico e enzimático são importantes a serem consideradas ao desenvolver estratégias de conservação e manejo pós-colheita, específicas para cada variedade.

Palavras-chave: catalase, peroxidase, açúcares solúveis, superóxido dismutase, tuberose.

\section{Introduction}

The tuberose (Polianthes tuberosa L.), also known as angelica in Brazil or as nardo, amole, tuberosa blanca ('white tuberose'), amiga de noche ('night friend'), azucena and vara de San José ('St. Joseph's staff') in many Spanishspeaking countries of Latin America, is an herbaceous, perennial plant native to Mexico that was disseminated across the globe during the 16th century (González, 2016).
It occupies an important position among bulbous crops as it remains a popular floral note in perfumery and can be used as both a cut-flower and pot ornamental (Kameswari et al., 2014). Tuberose inflorescences can reach $90 \mathrm{~cm}$ in height and may contain 30 flowers or more - all of which open acropetically (Pérez et al., 2019). In Mexico, the states of Morelos, Oaxaca, Guerrero, Veracruz and Puebla concentrate most of the country's commercial production (306.15 hectares in all 5 states combined) and generate 61.9

*Corresponding autor: yoyaly83@gmail.com 
million pesos annually (approximately 3.0 million USD). In Morelos alone, the tuberose ranks among the most important cut-flower crops in terms of revenue (SIAP, 2020).

The single-flowered tuberose variant is known agronomically as 'Mexican Single' (or as 'Mexicano' in Spanish), whereas the double-flowered cultivar is known as 'The Pearl' (or 'Perla'). Internationally recognized cultivars also include the plants known as 'Doble Excelsior', 'Tall Double', 'Florentiu' and 'Orange Flower' (González, 2016), as well as the Indian 'Shiringar', Vaibhav', 'Calcutta Doble' and 'Prajwal' (Pérez et al., 2019). Although infield and post-harvest behavior have been studied in many commercial varieties, this has not been the case in 'Mexican Single' or 'The Pearl', where such information is generally lacking. Thus, further production and commercialization remain an obstacle, at least in Mexico.

Compounding this is the short longevity of the flowers themselves. For instance, a commonly used harvest index is the presence of 2-3 open buds on a spike. Flowers cut this way, however, last approximately 3 days - and the whole inflorescence a further 4-7 days (7-10 days total) (Pérez et al., 2019). Additionally, less than $50 \%$ of buds usually open after harvest and the rest generally fall after several days (Wahitaka et al., 2001). Tuberose vase life can be extended either by pulsing with certain chemicals or by immersing in preservative solutions. Pulsing with $2-4 \%$ sucrose, for instance, increases the number of open flowers (Wahitaka et al., 2001) whereas pulsing with 4-20\% sucrose alone or in combination with hydroxyquinoline citrate $(200 \mathrm{mg}$ $\left.\mathrm{L}^{-1}\right)$, citric acid $(2 \%)+$ silver nitrate $\left(20 \mathrm{mg} \mathrm{L}^{-1}\right)$ or silver thiosulfate (1-2 mM), increases both postharvest life (10 and 20 days, respectively) and floral opening (60-88\%) (Pérez et al., 2019).

Arief (2016) attributes the success of floriculture in developed countries like the Netherlands to an increased understanding of the postharvest physiology and senescence of commercially important species. Similarly,
Mexico stands to benefit from continued research on the tuberose, especially when considering many postharvest biochemical processes remain obscure. This study therefore, seeks to evaluate the effect of pulsing on the postharvest behavior of cut tuberose and determine if any differences exist between 'Mexican Single' and 'The Pearl' - two commercially important cultivars for the state of Morelos, Mexico. To this end, a series of physical (fresh weight, water uptake, numbers of open and senescent flowers, CIE $\mathrm{L}^{*} \mathrm{C}^{*} \mathrm{~h}$ values), physiological (respiration rates, total sugars) and enzymatic measurements (peroxidase, catalase and superoxide dismutase activities) were performed, which allowed us to better outline their general response to treatment.

\section{Materials and Methods}

\section{Biological material}

Tuberose spikes from the cultivars 'Mexican Single' and 'The Pearl' were harvested from commercial flower beds located near the town of Cuahuchichinola (municipality of Mazatepec), State of Morelos, Mexico. Initially, 100 spikes from each variety were collected. Harvesting occurred at 8:00 am and the stems were quickly transported (without water) to the Agricultural Production Laboratory.

\section{Postharvest treatments}

Spikes lacking pathogen damage and with 1-2 basal buds open were selected, cut to a length of $80 \mathrm{~cm}$ and randomly sorted into groups of 25 (two for each cultivar). One group was pulsed with a solution containing $20 \%$ sucrose and $200 \mathrm{mg}$ of hydroxyquinoline citrate (sucrose + HQC, i.e. the experimental treatment), while the other was left standing in tap water (i.e. the control). In these experiments, pulsing occurred over a period of 24-hours (see Table 1). Damaged or deteriorated spikes were excluded from further processing and study.

Table 1. Postharvest treatments evaluated in the tuberose cultivars 'Mexican Single' and 'The Pearl' $\left(20 \pm 2{ }^{\circ} \mathrm{C} ; 50 \%-60 \%\right.$ HR).

\begin{tabular}{|c|c|c|c|}
\hline Treatments $(\mathbf{n}=\mathbf{2 5})$ & Pulsing time & Sucrose & HQC \\
\hline 'Mexican Single', unpulsed & $24-\mathrm{h}$ & $0 \mathrm{~g} \mathrm{~L}^{-1}$ & $0 \mathrm{mg} \mathrm{L}^{-1}$ \\
\hline 'Mexican Single', pulsed & $24-\mathrm{h}$ & $200 \mathrm{~g} \mathrm{~L}^{-1}$ & $200 \mathrm{~m} \mathrm{~L}^{-1}$ \\
\hline 'The Pearl', unpulsed & $24-\mathrm{h}$ & $0 \mathrm{~g} \mathrm{~L}^{-1}$ & $0 \mathrm{~m} \mathrm{~L}^{-1}$ \\
\hline 'The Pearl', pulsed & $24-\mathrm{h}$ & $200 \mathrm{~g} \mathrm{~L}^{-1}$ & $200 \mathrm{~m} \mathrm{~L}^{-1}$ \\
\hline
\end{tabular}

HQC: hydroxyquinoline citrate.

The remaining spikes were then placed inside graduated cylinders (glass, 1 L capacity) and further sorted into two groups: one to effectuate destructive measurements $(n=6$, once every 3 days), the other to effectuate non-destructive ones ( $\mathrm{n}=8$, once every 2 days). An experimental unit therefore, consisted of a single tuberose spike from each variety with 5 or 7 more used as replicates.

\section{Fresh weight}

This was determined on an OHAUS ${ }^{\circledR}$ digital scale (Ohaus Corporation, Pine Brook, NJ, USA). Measurements were made every 2 days and used along with initial weight (taken to be $100 \%$ ) to calculate the relative fresh weight of a spike. Results were expressed as percentages. 


\section{Water uptake}

Individual spikes were placed inside graduated cylinders (glass, 1 L capacity) along with $500 \mathrm{~mL}$ of tap water. After two days, the difference in water volume was recorded. The entire volume of water was replaced after each assessment. Results were recorded in $\mathrm{mL}$.

\section{Visual quality and chromatic measurements}

The appearance of each spike was evaluated using a 5-point hedonic scale where $5=$ excellent (turgid flowers, no wilting) and $1=$ senescent (wilting flowers). The numbers of open and senescent flowers were also determined, as were the CIE $\mathrm{L}^{*} \mathrm{C} * \mathrm{~h}$ values in four randomly selected florets using a portable spectrophotometer (Mod. 3290, X-rite ${ }^{\circledR}$ Inc., Grand Rapids, Michigan, USA). All three assessments were performed every two days.

\section{Respiration}

A static system was used to quantify the amount of $\mathrm{CO}_{2}$ emitted during respiration (Salveit, 2016). For this, individual spikes were first placed inside 3 L-airtight containers for $2-\mathrm{h}$. Subsequently, a $1 \mathrm{~mL}$ sample of headspace air was taken and injected into an Agilent 7890A system (Agilent Technologies, Santa Clara, CA, USA) equipped with a thermal conductivity detector (TCD). The injector, oven, and TCD temperatures were $180^{\circ} \mathrm{C}, 80^{\circ} \mathrm{C}$, and $170{ }^{\circ} \mathrm{C}$, respectively. Nitrogen was used as the carrier gas. Analytical-grade $\mathrm{CO}_{2}$ standards (Praxair $\AA$, Mexico) were used for these determinations. Results were expressed as $\mathrm{mL}$ of $\mathrm{CO}_{2} \mathrm{~kg}^{-1} \mathrm{~h}^{-1}$.

\section{Total sugars (TS)}

For each spike, $1 \mathrm{~g}$ of tuberose flowers was first picked, chopped finely and then added to an $80 \%$ alcohol solution. The mixture was subsequently boiled for $5 \mathrm{~min}$ and stored at $4{ }^{\circ} \mathrm{C}$ for 15 days. After storage, a $1 \mathrm{~mL}$ aliquot of the supernatant was dried and mixed with $20 \mathrm{~mL}$ of $\mathrm{dH}_{2} \mathrm{O}$. One milliliter of this was then added to $2 \mathrm{~mL}$ of anthrone solution ( $0.4 \mathrm{~g}$ in $100 \mathrm{~mL}$ of sulfuric acid) while on an ice bath. The mixture was boiled for $5 \mathrm{~min}$ and returned to the ice bath to cool. Its absorbance at $600 \mathrm{~nm}$ was then measured (Genesys $^{\mathrm{TM}}$ 10S UV-Vis, Thermo Fisher Scientific, USA) and used - together with a glucose calibration curve - to calculate the concentration of sugars in the sample. Results were expressed as $\mathrm{mg}$ of total sugars $\mathrm{g}^{-1} \mathrm{FW}$ (Whitham et al., 1971).

\section{Antioxidant enzymes}

Peroxidase (EC 1.11.1.7; POD), catalase (EC 1.11.1.6; CAT), superoxide dismutase (EC. 1.15.1.1; SOD) and soluble proteins were extracted from the petals of florets. Enzyme assays and protein quantification were performed as indicated by (Pérez et al., 2014). Enzyme activity was reported as $\mathrm{U} \mathrm{g}^{-1} \mathrm{FW}$

All data were subject to variance analysis (one-way ANOVA; $\mathrm{P} \leq 0.05$ ) and Tukey's comparison of means ( $p \leq$ $0.05,0.01$ and 0.0001). For these, the GLM and MEANS commands in the SAS statistical package were used (V.9.2, SAS Institute Inc., Cary, NC).

\section{Results and Discussion}

\section{Relative fresh weight and water uptake}

There was a $16 \%-23 \%$ increase in the relative fresh weight of pulsed spikes compared to controls (Figure 1A). The latter was true regardless of cultivar type ('Mexican Single' or 'The Pearl') and was likely due to both an increase in water uptake (hydration) and a reduction in weight loss as mentioned by Pérez et al. (2016). This is the first report of post-harvest behavior in 'Mexican Single', however, and it is remarkable that its response to pulsing be so similar to that of 'The Pearl' - at least in this regard (Figure 1 A).

The highest water uptake in both cultivars occurred on day 3 (Figure 1B). Afterwards, values decreased significantly, though they continued to be higher in 'The Pearl' independent of pulsing. Pulsing did, however, increase water uptake in both varieties, though this was perhaps more apparent in 'The Perl'. Thus, inter-varietal differences are still important, even though the general response to treatment is quite similar.

\section{Visual quality}

The appearance of all cultivars and treatments was scored as 'excellent' (i.e. turgid flowers, no wilting) until day 3 (Figure $1 \mathrm{C}$ ). By day 5 however, differences could be seen. This was more obvious in the unpulsed spikes of 'The Pearl' (judged only as 'fair') followed by the pulsed and unpulsed spikes of 'The Pearl' and 'Mexican Single', respectively (both scored as 'good'). The pulsed spikes of 'Mexican Single', on the other hand, retained an appearance score close to 'excellent' even on day 5. By day 7 , however, average scores dropped to values intermediate between 'good' and 'fair'. The visual quality of the pulsed and unpulsed spikes of 'The Pearl' and 'Mexican Single' also suffered, but in their case, average scores fell to values closer to 'fair' (i.e. partially turgid).

Spikes of 'The Pearl' have also been reported as 'fair' after 5-6 days (using a similar hedonic scale), or as 'good' for a comparable period (i.e. 5 days), but only after pulsing (Pérez et al., 2015). Nevertheless, the postharvest life of tuberose inflorescences can potentially last nearly two weeks (4-13.3 days). This large variation has been attributed by some either to the type of water being used (tap, distilled, deionized, etc.) or to the particular cultivar studied (Pérez et al., 2019).

\section{Open and senescent flowers}

The average number of open buds in 'Mexican Single' and 'The Pearl' was 1 and 2, respectively, at the beginning of the experiment (Figure 1 D). By the end, however (i.e. on day 7), 16-17 buds opened fully in 'The Pearl' whereas only 8-10 did so in 'Mexican Single'. Pulsing had, additionally, no statistically significant effect on the number of flowers that subsequently opened in either cultivar. By comparison, Jowkar and Salehi (2005) report 9-10.75 open flowers after 7-8 days in the variety known as 'Gol Dorosht' - a range similar to that of 'Mexican Single', but inferior to the one in 'The Pearl'. 
Senescent flowers, on the other hand, increased considerably from day 5 onwards (Figure $1 \mathrm{E}$ ). The number was always greatest in the unpulsed spikes of 'The Pearl' and lowest in the pulsed spikes of 'Mexican Single'. 'The Pearl', therefore, has a greater flowering capacity (i.e. number of buds able to open fully) than 'Mexican Single', but its flowers will, unfortunately, deteriorate more easily. Underlying genetic differences might thus also play a role in the response of these two cultivars to postharvest treatment and management.

\section{Chromatic values}

Flower petals in 'The Pearl' experienced peak lightness (i.e. maximum shift towards white) on day 3 irrespective of pulsing ( $\mathrm{L}^{*}=77.5-72.4$, see Figure $1 \mathrm{~F}$ ). Afterwards, $\mathrm{L}^{*}$ decreased noticeably (e.g. on day 5 ) and continued to do so until the end of the experiment. 'Mexican Single', on the other hand, experienced maximum values of $\mathrm{L}^{*}$ on the fifth day - though these were not nearly as high as those of 'The Pearl' on day 3. Interestingly, Pérez et al. (2015) report a similar range of values in 'The Pearl' $\left(\mathrm{L}^{*}=74.5-83.1\right)$, though in their case, lightness peaks last for 6 days. Naturally, a decline in $\mathrm{L}^{*}$ affects the display life of flowers as it usually leads to a darkening of petals (as occurs, for example in roses; Pietro et al., 2012). However, our results highlight both the subtle differences in "white" that characterize the flowers of these cultivars, and the fact that such differences coincide with (and are likely associated to) a greater uptake of water (see Figure $1 \mathrm{~B}$ and $\mathrm{F}$ ).

Similar to $L^{*}$, chromaticity peaked on day 3 in the pulsed florets of 'Mexican Single' and 'The Pearl' and, to a lesser extent, in the unpulsed florets of the latter as well (Figure 1 G). Peak chromaticity was also experienced on day 5 in the unpulsed florets of 'Mexican Single', just as occurred with peak lightness. In both cultivars, it was clear that pulsing caused a statistically significant increase in the value of $C^{*}$. Our results, therefore, are congruent with those of Pérez et al. (2015) in 'The Pearl', who likewise report a decline in $\mathrm{C}^{*}$ over a comparable period of time (5 days, though in this case the change is small, from $\mathrm{C}^{*}=21.5-18.1$ ).

The value of $\mathrm{C}^{*}$ indicates the degree to which a particular color is vivid (high $\mathrm{C}^{*}$ ) or dull (low $\mathrm{C}^{*}$ ) (Castricini et al., 2017). As tuberoses are white and generally lack pigments (e.g. carotenoids, anthocyanins, etc.; Huang et al., 2001), variations in $\mathrm{C}^{*}$ are likely not associated with these or with any of their degradation products. Instead, they could be linked to other short-term changes in their cells that are initiated by pulsing.

Unlike $\mathrm{L}^{*}$ and $\mathrm{C}^{*}$, hue increased continuously over 5 days in all evaluated treatments (from $\mathrm{h}=81.5-91.2$ to $\mathrm{h}=$ 94.4-98.9; see Figure $1 \mathrm{H}$ ). This implicated a shift towards "yellow" in the CIE color space. Only the unpulsed florets of 'Mexican Single' experienced a slower rate of change during the first 3 days. They did, however, reach values comparable with those in the rest of the treatments. Pérez et al. (2015) report similar changes in 'The Pearl' - specifically, values that increase from 80-99 over the course of 5 days.

\section{Respiration rate}

The rapid development of buds and flowers requires large amounts of energy, which are normally supplied by higher respiration rates. In cut tuberose, peak rates occur just a few days after harvest, with values of 137.4 $\mathrm{mLCO}, \mathrm{kg}^{-1} \mathrm{~h}^{-1}$ (after $4-5$ days at $21^{\circ} \mathrm{C}$ ) and of $40-46 \mathrm{~mL}$ $\mathrm{CO}_{2} \mathrm{~kg}^{-1} \mathrm{~h}^{-1}$ (after 3 days at $20-22{ }^{\circ} \mathrm{C}$ ) having previously been reported (Jeenbuntug et al., 2007; Pérez et al., 2015; 2016). In this study, peak rates occurred on the very first day of monitoring (Figure 2A) after which they declined substantially (day 4) before recuperating again - either fully or in part - after a week (day 7). 

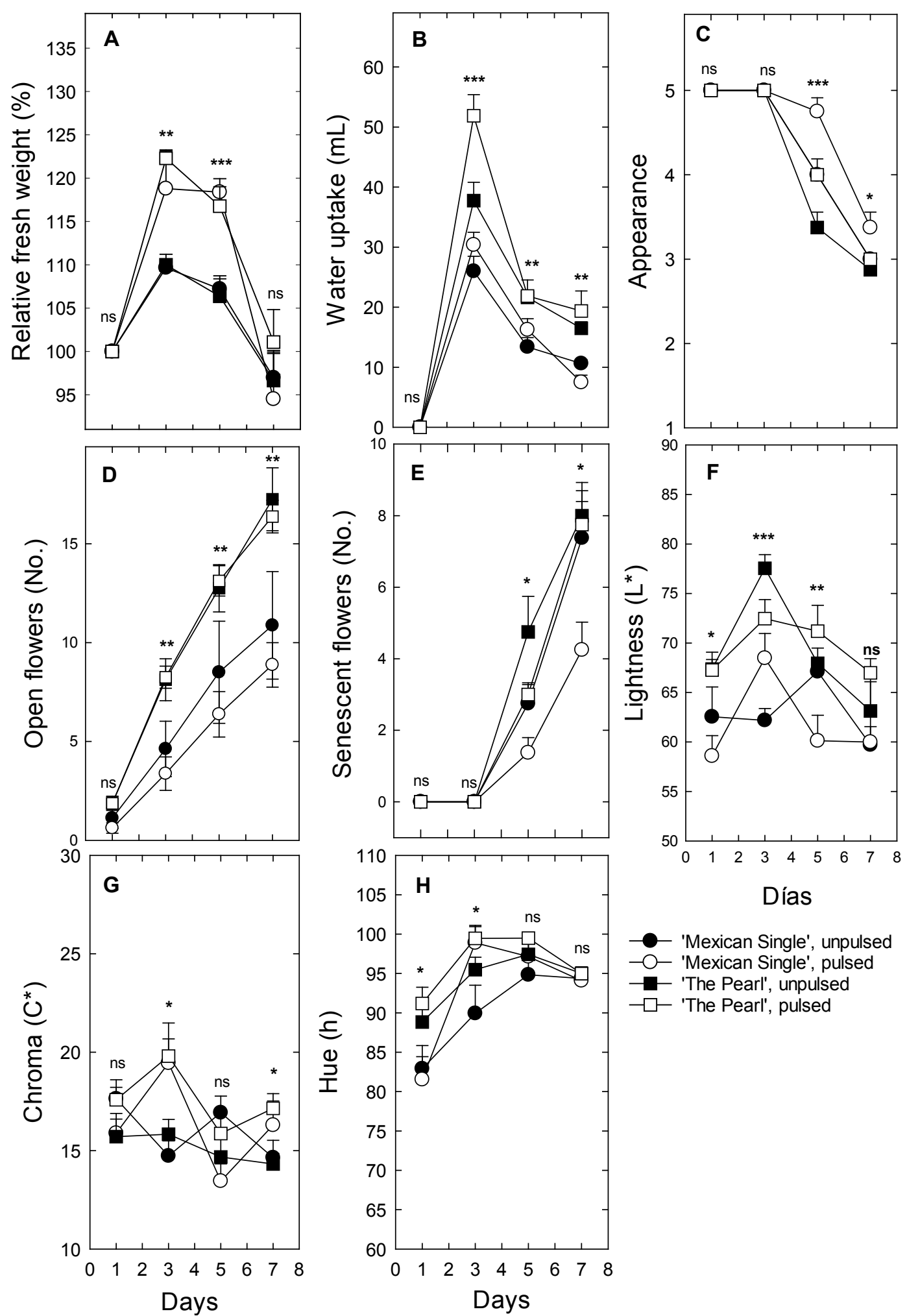

Días

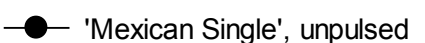

- - 'Mexican Single', pulsed

- 'The Pearl', unpulsed

$-\square-$ 'The Pearl', pulsed

Figure 1. Physical postharvest changes in the pulsed and unpulsed spikes of 'Mexican Single' and 'The Pearl' (Polianthes tuberosa L.). Each point represents the mean of eight measurements \pm 1 standard error. ns, not significant; *, significant at $p \leq 0.05 ; * *$, significant at $p \leq 0.01 ; * * *$, significant at $p \leq 0.0001$. 

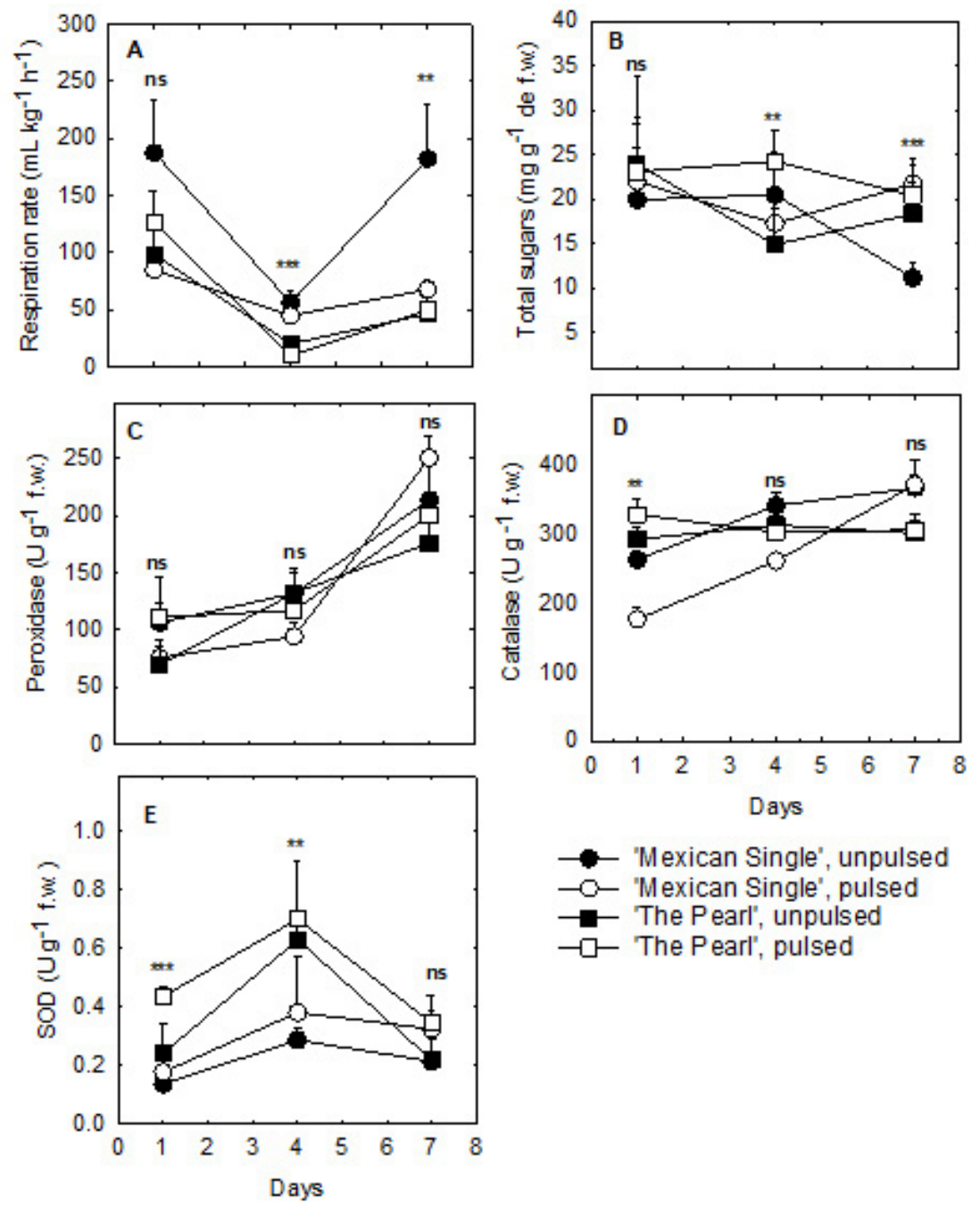

Figure 2. Physiological and enzymatic postharvest changes in the pulsed and unpulsed spikes of 'Mexican Single' and 'The Pearl' (Polianthes tuberosa L.). Each point represents the mean of six measurements \pm 1 standard error. ns, not significant; $*$, significant at $p \leq 0.05 ; * *$, significant at $p \leq 0.01 ; * * *$, significant at $p \leq 0.0001$.

This trend was observed in all treatments, including controls, and was probably the result of postharvest handling. After all, both ethylene production and respiration rates increase in cut flowers as a result of stress (Pérez et al., 2019). It is therefore likely that initial rates reflect this and that the subsequent peak on day 7 results from a higher energy demand from developing flowers. Evidence for this comes from the similarly higher number of senescent flowers present during this time (Figure 1E). Coincidently, higher rates of ethylene production $\left(4.93 \mu \mathrm{L} \mathrm{kg}^{-1} \mathrm{~h}^{-1}\right)$ are also associated with increased numbers of open basal buds in cv. Double (Jeenbuntug et al., 2007).

Despite respiration maxima occurring on days 1 and 7, pulsing triggered a more nuanced response in 'Mexican Single'. The inflorescences from this cultivar also had fewer numbers of senescent flowers and received visual scores of 'excellent' (Figure 1, C and E). Thus, treatment with sucrose + HQC not only extends postharvest life in
'Mexican Single' but also benefits its overall appearance. In contrast, the respiration rates of 'The Pearl' on days 1, 4 and 7 were quite similar even with pulsing, indicating that treatment with sucrose + HQC had no noticeable effect on the physiological processes of this cultivar.

\section{Total sugars (TS)}

High rates of respiration in cut flowers require considerable amounts of carbohydrates, which may accumulate in stems, leaves, and petals (as starch and sugars) under the right climactic conditions provided certain horticultural practices are followed. It is common practice, however, to cut flowers early in the morning when their water content is high and their carbohydrate reserves are low, which is why they stand to benefit from treatment with sugar-containing solutions - usually for a few seconds to several hours - immediately after harvest (Reid, 2002a; Kumar et al., 2017). According to Hutchinson et al. (2003) 
carbohydrates like sucrose can act not only as respiratory substrates but also as osmolytes, improving water balance and maintaining the turgor of tissues, especially in petals.

In this study, the TS content of most treatments was initially quite similar (19.9-23.9 $\left.\mathrm{mg} \mathrm{g}^{-1} \mathrm{FW}\right)$, remaining more or less stable over the course of a week (17.7-21.7 mg $\mathrm{g}^{-1} \mathrm{FW}$ on day 7 , see Figure $2 \mathrm{~B}$ ). However, a noticeable decline occurred in the unpulsed florets of 'Mexican Single' during this period (down to $11.1 \mathrm{mg} \mathrm{g}^{-1} \mathrm{FW}$ on day 7). In fact, the difference between initial and final values of TS was considerably larger in this treatment $\left(\Delta \mathrm{TS}=8.8 \mathrm{mg} \mathrm{g}^{-1}\right.$ $\mathrm{FW})$ than in all others ( $\Delta \mathrm{TS}=2.2 \mathrm{mg} \mathrm{g}^{-1} \mathrm{FW}$ on average). This change coincided with an increase in the rate of respiration in the spikes themselves (see Figure 2A, day 7). These results suggest a faster use of respiratory substrates in this variety of tuberose ('Mexican Single'), which does occur in many cut flowers during the process of senescence (Arief, 2016). By comparison, no noticeable trend could be discerned among the pulsed florets of 'Mexican Single' or in the pulsed and unpulsed florets of 'The Pearl', though the lowest concentrations of TS for some of them occurred on day 4 of the experiment.

\section{Antioxidant enzymes}

Peroxidase (POD) activity was similar in all treatments (69.8-106.6 $\mathrm{U} \mathrm{g}^{-1} \mathrm{FW}$ ) and followed the same general profile: increasing slightly on day 4 (94.4-132 $\left.\mathrm{U} \mathrm{g}^{-1} \mathrm{FW}\right)$ and more noticeably on day 7 (178-250.7 $\mathrm{U} \mathrm{g}^{-1} \mathrm{FW}$ ) (Figure $2 \mathrm{C})$. POD - along with other enzymes and antioxidant compounds - reduces hydrogen peroxide $\left(\mathrm{H}_{2} \mathrm{O}_{2}\right)$ and other oxygen species (Taiz et al., 2015) that would otherwise react and degrade lipids, proteins and nucleic acids, leading to senescence and cell death (Saeed et al., 2014). Interestingly, the intensity of POD activity reflects the degree of tissue damage, at least during the process of ripening and over-ripening in strawberries (Singh et al., 2012). Our results with POD suggest no real differences between 'Mexican Single' and 'The Pearl' in terms of activity. Pulsing, likewise, appears to confer no additional advantages to either of these cultivars.

Catalase (CAT) activity was more or less constant throughout the experiment in the pulsed and unpulsed florets of 'The Pearl' (62.5-291 U g ${ }^{-1} \mathrm{FW}$ at the start vs. $366.1 \mathrm{U} \mathrm{g} \mathrm{g}^{-1} \mathrm{FW}$ at the end, see Figure $2 \mathrm{D}$ ); not so in 'Mexican Single', where activity increased continuously until day 7. This was more evident in the pulsed treatment, which overall, experienced a $106 \%$ increase in activity. CAT converts $\mathrm{H}_{2} \mathrm{O}_{2}$ to oxygen $\left(\mathrm{O}_{2}\right)$ during cut-flower senescence (Bhattacharjee et al., 2015) and, in gladiolus, activity remains constant for 10 days (Saeed et al., 2014). Our results, therefore, suggest that the pulsed florets of 'Mexican Single' are able to maintain a lower state of oxidative stress for nearly 7 days; afterwards, values become quite similar to those of untreated flowers.

Superoxide dismutase (SOD) activity was generally highest in 'The Pearl' (Figure 2 E). Both cultivars, however, experienced peak activities on day $4(0.28-0.3$ $\mathrm{U} \mathrm{g}^{-1} \mathrm{FW}$ in 'Mexican Single'; 0.6-0.7 $\mathrm{U} \mathrm{g}^{-1} \mathrm{FW}$ in 'The Pearl'). This is similar to what occurs in carnations during senescence, where SOD activity also increases during the first 4 days only to decline afterwards (Song et al., 2014). SOD - which is generally found in chloroplasts, peroxisomes, mitochondria, the cytosol and the apoplast - simultaneously reduces and oxidizes superoxide anion $\left(\mathrm{O}_{2}{ }^{-}\right)$to produce $\mathrm{H}_{2} \mathrm{O}_{2}$ and $\mathrm{O}_{2}$ according to the reaction: $2 \mathrm{O}_{2}^{--}+2 \mathrm{H}^{+} \rightarrow \mathrm{O}_{2}+\mathrm{H}_{2} \mathrm{O}_{2}$ (Taiz et al., 2015). Our results, therefore, suggest that flowers in 'The Pearl' have a greater capacity to avoid oxidative stress because of their higher SOD activities.

\section{Conclusions}

Pulsing with 20\% sucrose and $200 \mathrm{mg}$ of hydroxyquinoline citrate (sucrose + HQC) increased water uptake and the relative fresh weight of cut spikes in the tuberose cultivars 'Mexican Single' and 'The Pearl'. Visual quality was better in the former even 5 days after harvest, and its unpulsed inflorescences had the highest rates of respiration, consumption of total sugars (TS) and catalase (CAT) activities. 'The Pearl' on the other hand, had the greatest flowering capacity (i.e. number of buds able to open fully), although its florets deteriorated more easily, even after pulsing with sucrose + HQC. 'Mexican Single' therefore, has the highest quality overall, and the beneficial effects of pulsing are more readily observed in its inflorescences than in those of 'The Pearl'.

\section{Author contribution}

SLFS: Experiment design, data analysis, laboratory work, manuscript writing. GAPA: Experiment design, data analysis, manuscript writing; IAT: Experiment design, data analysis, laboratory work, manuscript writing. VLM: Experiment design, data analysis, laboratory work, manuscript writing; CPZ: Experiment design, data analysis, laboratory work, manuscript writing. PJL: Experiment design, data analysis, laboratory work, manuscript corrections. DSG: Experiment design, data analysis, laboratory work, manuscript corrections.

\section{Acknowledgements}

We are grateful for the postgraduate scholarship awarded to Sandy Lizbeth Fernando-Santos by Mexico's National Council of Science and Technology (CONACyT). We would also like to thank B. Sc. (Hons.) Leonardo Castillo Pelayo for his assistance during the drafting of the English-language manuscript.

\section{References}

ARIEF, Z.M. Postharvest Physiology and Handling of Cut flowers. San Bernardino: Scholar's Press. 2016. 108p.

BHATTACHARJEE, D.; KRISHNATHAKUR, P.; SINGH, J.; DHUA, R.S. Flower senescence. In: WASIM, S.M. Postharvest biology and technology of horticutlural crops- Principles and practices for quality maintence. New Jersey: Apple Academic Press-CRC Press-Taylor and Francis Group, 2015. p.319-346. 
CASTRICINI, A.; ALMEIDA, E.F.A.; REIS， J.B.R.; SILVA, S.L.O.; RODRIGUES, M.G.V.; SOUZA, G.S.B Postharvest aspects of roses. Ornamental Horticulture, v.23, n.2, p.160-165. 2017. DOI: https://doi.org/10.14295/ oh.v23i2.990.

GONZÁLEZ, V.M.E. Polianthes tuberosa L.: Revisión de sus aspectos filogenéticos, morfológicos y de cultivo. Cultivos Tropicales, v.37, p.120-136, 2016. DOI: https:// doi.org/10.13140/RG.2.1.2715.4161.

HUANG, K.-L.; MIYAJIMA, I.; OKUBO, H.; SHEN, T.M.; HUANG, T.-S. Flower colours and pigments in hybrid tuberose (Polianthes). Scientia Horticulturae, v.88, p. 235-241, 2001. DOI: https://doi.org/10.1016/S0304$4238(00) 00213-2$.

JEENBUNTUG, J.; BUANONG, M.; KANLAYANARAT, S. Study of sucrose pulsing treatment on physiological changes of tuberoses (Polianthes tuberosa) after harvest. Acta Horticulturae, v.755, p.425-428, 2007.

JOWKAR, M.M.; SALEHI, H. Effects of different preservative solutions on the vase life of cut tuberose flowers at usual home conditions. Acta Horticulture, v.669, p.411415, 2005. DOI: 10.17660/ActaHortic.2005.669.54.

KAMESWARI, P.L.; GIRWANI, A.; RADHARANI, K. Genetic diversity in tuberose (Polianthes tuberose L.) using morphological and ISSR markers. Electronic Journal of Plant Breeding, v.5, n.1, p. 52-57, 2014.

KUMAR, S.; BARMAN, K.; SHARMA, S. Postharvest management of commercial flowers. In: WASIM, M.S. (Ed.). Postharvest management of horticultural crops. Practices for quality preservation, Ames: Apple Academic Press-CRC Press-Taylor \& Francis Group, 2017. p.91-150.

PÉREZ, A.G.A.; ALIA, T.I.; VALDEZ, A.L.A.; COLINAS, L.M.T.; LÓPEZ, M.V.; SAINZ, A.M.J. La refrigeración en húmedo y seco afecta la vida poscosecha de flores de corte de lisianthus (Eustoma grandiflorum) 'ABC Blue Rim'. Revista Mexicana de Ciencias Agrícolas, v.5, n.7, p.1247-1260, 2014.

PÉREZ, A.G.A.; ALIA, T.I.; COLINAS, L.M.T.; SAINZ, A.M. de J.; ALVAREZ, V.J.E. Aplicación de 1-metilciclopropeno en inflorescencias de nardo (Polianthes tuberosa L.) en poscosecha. Acta Agrícola y Pecuaria, v.1, n.1, p. 29-36, 2015.

PÉREZ, A.G.A.; ALIA, T.I.; COLINAS, L.M.T.; VALDEZ, A.L.A. Daño mecánico por compresión en nardo (Polianthes tuberosa). Revista Mexicana de Ciencias Agrícolas, v.7, n.1, p.103-113, 2016.
PÉREZ, A.G.A.; ALIA, T.I.; COLINAS, L.M.T.; VALDEZ, A.L.A.; PELAYO, Z.C. Postharvest physiology and technology of the tuberose (Polianthes tuberosa L.): an ornamental flower native to Mexico. Horticulture, Environment, and Biotechnology, v.60, p.281-293, 2019. DOI: https://doi.org/10.1007/s13580-018-00122-4.

PIETRO, J.; MATTIUZ, B.; MATTIUZ, C.F.M.; RODRIGUES, T.J.D. Qualidade de rosas de corte tratadas com productos naturais. Ciencia Rural, v.42, n.10, p.17811788, 2012.

SAEED, T.; HASSAN, I.; AKHTAR, N.; JILANI, G. Effect of gibberelic acid on the vase life and oxidative activities in senescing cut gladiolous flowers. Plant Growth Regulation, v.72, p.89-95, 2014. DOI: https://doi. org/10.1007/s10725-013-9839-y.

SALVEIT, M.E. Respiratory Metabolism. In: PAREEK, S. Postharvest Ripening Physiology of Crops. Boca Raton: CRC Press - Taylor and Francis, 2016. p.139-156.

SIAP. 2020. Cierre de la producción agrícola por cultivo (1980 - 2018). Available at: <nube.siap.gob.mx/ cierreagricola $>$. Accessed on Mar $22^{\text {th }} 2020$.

SONG, L.-L.; LIU, H.; YOU, Y.-L.; SUN, J.; Y.I., C; L.I., Y.-B.; JIANG, Y.-M.; WU, J.-S. Quality determinations of cut Carnation flowers involves in antioxidant systems and energy status. Scientia Horticulturae, v.170, p.45-52, 2014. DOI: https://doi.org/10.1016/j.scienta.2014.02.035.

SINGH, S.P.; SINGH, Z.; SWINNY, E.E. Climateric level uring fruit ripening influences lipid peroxidation and enzymatic and non-enzymatic antioxidative systems un Japanese plums (Prunus salicina Lindell). Postharvest Biology and Technology, v.65, p.22-32, 2012. DOI: https:// doi.org/10.1016/j.postharvbio.2011.10.007.

TAIZ, L.; ZEIGER, E.; MOLLER, I.M.; MURPHY, A. Plant Physiology and Development. Sunderland, Sinauer, 2015. 761p.

WAHITAKA, K.; REID, M.S.; DODGE, L.L. Cold storage and flower keeping quality of cut tuberose (Polianthes tuberosa L.). Journal of Horticulture, Science and Biotechnology, v.76, p. 271-27, 2001. DOI: 10.1080/14620316.2001.11511362.

WHITHAM, F.H.; BLAYDES, D.F.; DEVLIN R.M. Experiments in plant physiology. Van Nostrand Reinhold Company, New York, 1971, pp. 55-58. 